\author{
Witold Statkiewicz \\ Institute of Logistics and Warehousing \\ e-mail: witold.statkiewicz@ilim.poznan.pl \\ Joanna Sobkowiak \\ Małkowski-Martech S.A. \\ e-mail: joanna.sobkowiakjs@gmail.com
}

\title{
IMPLEMENTING IOT (INTERNET OF THINGS) SOLUTIONS ON THE BASIS OF PROCESS ANALYSIS AND DESIGN THINKING (ON THE EXAMPLE OF A PRODUCTION COMPANY)
}

\begin{abstract}
The aim of this article is to outline the process of implementing changes within an organization, which are meant to achieve competitive advantage. The study was conducted in a company with a complex production structure. The article presents selected process aspects, the most important change determinants, as defined by the authors, and selected methods of creating dedicated new Internet of Things related solutions such as combined process analysis with the usage of BPMN 2.0 standard and Design Thinking methodology. The chapter outlines suggested implementations and the framework of further studies.
\end{abstract}

Keywords: Technological processes, process analysis, BPMN 2.0, IoT (Internet of Things), development, innovation, Industry 4.0, Design Thinking.

\section{INTRODUCTION}

Due to advancing market needs and technological development, companies are required to continuously grow and analyse their operations. Polish companies in the era of 4:0 economy face the challenge of achieving competitive advantage in a technologically advanced business environment. The fourth industrial revolution assumes mass customization, i.e. effective production of diversified and even personalized products. This type of complex activity requires very specialized agile manufacturing [Fertsch, Cyplik and Hadaś 2010], which is based not only on technical advancement, but above all on changes in thinking about how to plan processes,

Statkiewicz W., Sobkowiak J., Implementing Iot (Internet of Things) Solutions on the Basis of Process Analysis and Design Thinking (on the Example of a Production Company) [in:] Adamczak M. et al., Digitalization of Supply Chains, Spatium, Radom 2019, p. 39-52. https://doi.org/10.17270/B.M.978-83-66017-86-3.4 
organize resources, and in a broader context - management at a different level of own business strategy.

The concept of process analysis of a production company should include an audit of the existing process and proposals for changes that take into account technologically advanced solutions.

Scattered research and development strategies, new software, Internet of Things (IoT), new communication and logistics channels [Rifkin 2012] - these are the areas giving the potential for very individual concepts in terms of strategy building. Specialists assume that one of the most important determinants of strategic management of enterprises in the business network will be innovation and new technologies, as well as reduction of human resources for process optimization. Specialists agree that the upcoming revolution will result in the emergence of new comprehensive models of economic activity. These business models will require innovative managerial skills to take full advantage of the opportunities offered by the fourth revolution. A management team prepared in this way will be able to use new theories and management methods. "Perhaps we are moving towards new ways of doing business, where the boundaries between innovation and profit, fun and seriousness (...) will be erased". [New directions in organization and management 2012]. Moreover, this thinking is overlapping with the contemporary use of technology, to which the level of user confidence is increasing. Process remodeling must therefore take into account business changes taking place in the economy and propose changes that take into account the latest technologies.

In the following article, the authors focused on the analysis of selected internal processes and proposing solutions related to the IoT, which are aimed at achieving a competitive advantage by more precise responding to customer needs.

Despite the choice of one scope of analysis, it turned out that both the problems and the effects of possible implementations extend to other processes, improving the functioning of the company in a broader context.

\section{RESEARCH OBJECTIVES}

The authors of the article attempted to combine process analysis with the Design Thinking method in order to develop and implement simple solutions related to the Internet of Things in a selected company representing small and medium-sized enterprises. The research goal was to 
verify the impact of using the above-mentioned methods in creating new innovative solutions within the organization.

The studied company is a producer with a specialized profile in construction field, which distributes their products throughout the country.

In terms of optimization the company $\mathrm{X}$, the research objectives included:

- finding areas inside the X company in need of improvement,

- creating a list of recommendations related to Internet of Things that could be adapted to in the areas indicated in the process analysis in company,

- estimating the benefits of implementing solutions.

\section{DESCRIPTION OF THE RESEARCH METHOD}

In the first stage of the study, a group of people employed in various departments of the company $\mathrm{X}$ was gathered and a number of preliminary interviews were conducted in order to learn more about the company characteristics and current needs. For further research the "customer acquisition process for periodic inspections in the Service Department" was chosen. In the second stage the process analysis was conducted. BPMN 2.0 notation was used to correctly reflect the processes taking place in the investigated organization. Application of this notation allows for unambiguous representation of processes occurring in the organization in a way that is understandable both, for persons directly implementing processes as well as for managers and IT specialists who implement process changes. The processes, illustrated by maps, constitute the starting point for further analysis [Ragin-Skorecka, Nowak 2017].

In the third stage, in order to create target solutions that could contribute to increase of the effectiveness of the process, workshops were conducted in accordance with the Design Thinking methodology based on process maps developed during previous stage of the project. Design Thinking, as a supporting method, allows for quick and precise detection of areas of potential improvements and development of a target model of a new process together with its prototyping, without incurring high costs. An additional benefit of joint workshop work on solutions is the understanding by team members of the nature of the developed changes, and the possibility of direct impact on their formation allows to identify with the possible implementation. This creative method is used to constructively solve the diagnosed problems.

Statkiewicz W., Sobkowiak J., Implementing Iot (Internet of Things) Solutions on the Basis of Process Analysis and Design Thinking (on the Example of a Production Company) [in:] Adamczak M. et al., Digitalization of Supply Chains, Spatium, Radom 2019, p. 39-52. https://doi.org/10.17270/B.M.978-83-66017-86-3.4 
In this particular case, the workshop was attended by the employees of the Service Department, to whom the examined processes were presented. In the abstract of the workshop the aim of the project, the definition of the problem and the challenges they bring with them were emphasized. It also outlined the expected changes and the values we want to achieve thanks to the process changes.

The workshop consisted of several phases:

\section{Project brief.}

Brief defined the problem identified at an earlier stage thanks to process analysis and map preparation (AS IS). The abstract of the workshop indicated the purpose of the project, the definition of the problem and the challenges. Expected changes were outlined.

2. Individual generation of ideas.

Workshop participants were asked to generate as many ideas as possible about how to make the expected changes.

\section{Group verification of ideas.}

All individual ideas in groups were verified. They were evaluated and classified. Each group selected one of the best ideas, which was then subjected to the process of refining.

4. Prototyping selected ideas.

Selected ideas were prototyped and presented in the forum for evaluation. In the fourth stage the best concepts of changes developed during the Design Thinking workshop had an impact on the final shape of maps, presenting the target way of functioning of a given process (TO BE). This allowed to easily and transparently compare the course of both processes (Current and Target).

In order to provide a thorough analysis and more accurate effectiveness, the process taking place in the Service Department has been extended to include the diagnosis of neighboring processes. The extensive review resulted in comprehensive solutions, whose effectiveness can be evaluated in the context of the entire company, and not only in the context of one department.

\section{DESCRIPTION OF THE RESEARCH RESULTS}

The process of implementing the IoT-related solutions in the X manufacturing company took three months. In the first phase of the project, the authors of the article tried to discern which processes are the most important from the point of view of customer service. Although $\mathrm{X}$ is an 
economic entity whose activity oscillates around the manufacture of specialized products, it was noticed at the beginning of the analysis that the improvement of processes related to the processing of internal information focused on customer service may be a determinant of development.

In the existing business model of the company, there are two separate departments which contact the customer and influence the number of orders received by the company and contracts signed. These are the Sales Department and the Service Department. Both of them work in cooperation with the Execution Department, which realizes the topics acquired by the trade and after the investment is completed, they transfer them to the Service Department. The task of the latter is to maintain relations with the end customer, acquire service orders and sign long-term inspection contracts.

The authors focused on the flow of intra-organisational information about realizations. The circulation of the offer or contract, which is transformed into a production order with an individual number and then the company's implementation, was analysed and finally it became the subject of preparation by the Service Department. In case of large investments, a contract is signed between $\mathrm{X}$ and the client, the details of which very often relate to the obligations of other departments, such as Construction, Production or Service Departments.

At the very beginning of order circulation, a Contract File is created, containing the most important information necessary for order processing. The above mentioned File circulates all sensitive departments of the company and is finally archived in the Service Department.

During discussions with individual departments and preliminary analysis, it was decided that two service processes will be subject to detailed mapping, the task of which is to obtain new contracts for service inspections and the course of inspections. There were several reasons for such decision. First of all, these processes have a large income potential, as the number of facilities supplied with the company's products throughout the country is growing every year, and each of them is a potential service client of X. The Service Department, in addition to acquiring customers for periodic inspection, also deals with complaints, defects and free inspection, which significantly reduces the sales effectiveness of the team. Therefore, it seemed to be a good idea to find a solution that would guarantee easier target customer service. Additionally, the implementation of new solutions in this department turned out to be faster and simpler during the preliminary analysis than in the case of other business paths of the company.

Statkiewicz W., Sobkowiak J., Implementing Iot (Internet of Things) Solutions on the Basis of Process Analysis and Design Thinking (on the Example of a Production Company) [in:] Adamczak M. et al., Digitalization of Supply Chains, Spatium, Radom 2019, p. 39-52. https://doi.org/10.17270/B.M.978-83-66017-86-3.4 
The estimated cost is much lower than in case of implementation of solutions in other departments, which has an additional impact on the positive approach of the Management Board to invest in changes that may bring long-term benefits.

Areas qualifying for improvement in the Service Department were identified in the course of research work. The mapped processes (Figure 1) revealed information gaps and activities which turned out to be duplication of data already entered by other X company departments. In order to make this process more complete and to be able to accurately illustrate the internal organisational problems accumulated in the studied area of the company, the authors also analysed the preceding stage of the process - the customer service process. It turned out to be necessary from the point of view of effectiveness of the proposed solutions. The problems of the Service Department did not start at the level of the team itself, but are the result of decisions and actions taken at an earlier stage of implementation. The effects of the analysed processes are accompanied by a high risk of failure due to failure to provide complete information necessary to undertake sales activities.

It was diagnosed that some of the activities in the process are possible to eliminate. These elements have been marked in blue on the AS IS charts and listed in Table 1. It applies to: analysis of Execution File, analysis of production order lists in xls file (by Service Department Manager), manual control of dates for offering service (by Service Department Specialist), KT product plate verification (by Service Crew and Service Department Specialist).

This applies to the preliminary analysis of production order lists, offer numbers in an xlx file and the review of the Execution File provided by the Execution Department. All these analyses are performed by the manager.

Statkiewicz W., Sobkowiak J., Implementing Iot (Internet of Things) Solutions on the Basis of Process Analysis and Design Thinking (on the Example of a Production Company) [in:] Adamczak M. et al., Digitalization of Supply Chains, Spatium, Radom 2019, p. 39-52. https://doi.org/10.17270/B.M.978-83-66017-86-3.4 


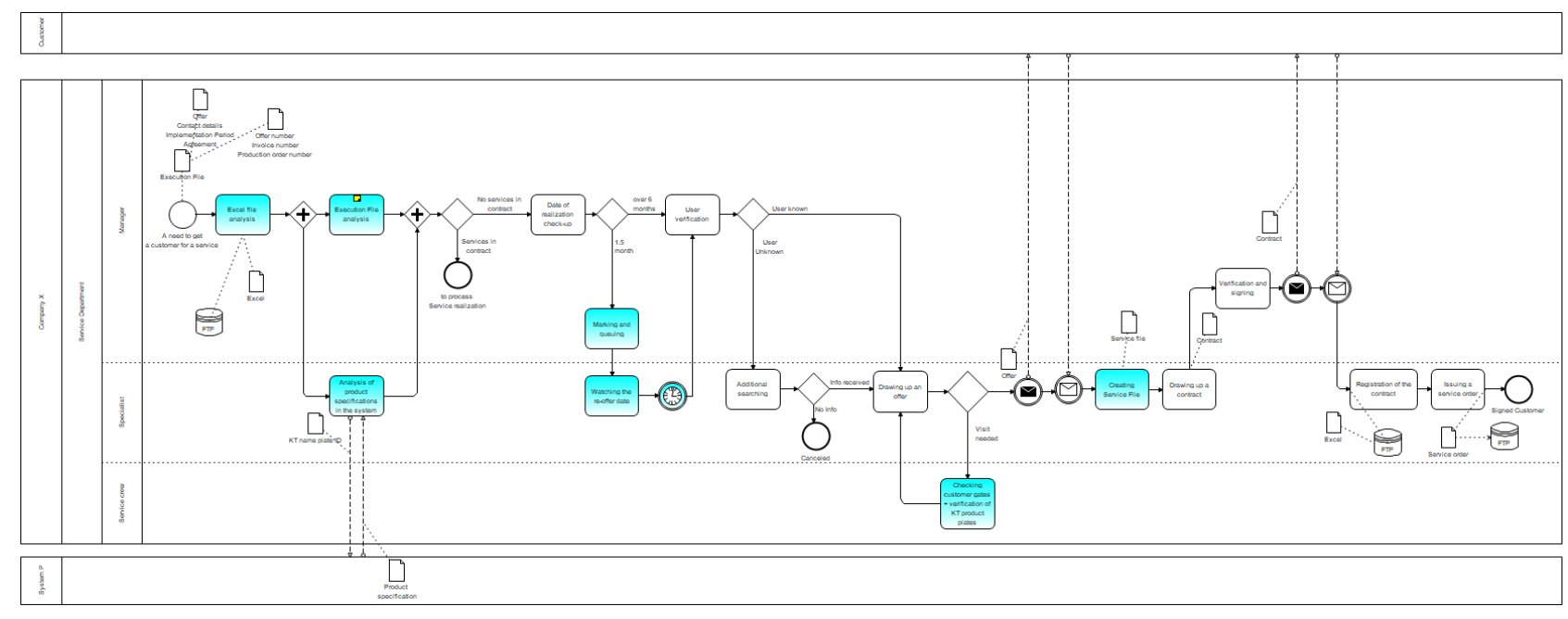

Fig. 1. Process of acquiring a customer for periodic service - current state (AS IS) Source: own elaboration.

Table 1. Areas selected for improvement in the process of acquiring customers for periodic service - current status of AS IS.

\begin{tabular}{|c|c|c|}
\hline $\begin{array}{l}\text { Areas identified for } \\
\text { improvement }\end{array}$ & Characteristic & Current state \\
\hline Analysis of Execution File & $\begin{array}{l}\text { All documents that are included: } \\
\text { - commercial offer, } \\
\text { - agreement, } \\
\text { - contact details and email arrangements, } \\
\text { - production order, } \\
\text { - invoice. }\end{array}$ & $\begin{array}{l}\text { Approximately } 7 \text { Execution } \\
\text { files per month }\end{array}$ \\
\hline $\begin{array}{l}\text { Analysis of production order } \\
\text { lists } \\
\text { (in xls file)Analysis of product } \\
\text { specifications in the system }\end{array}$ & $\begin{array}{l}\text { Contains all production orders for a given month. Helps } \\
\text { identify products on site. }\end{array}$ & $\begin{array}{l}\text { Approximately } 50 \\
\text { production orders per } \\
\text { month/ }\end{array}$ \\
\hline $\begin{array}{l}\text { Manual control of possible } \\
\text { service offer dates }\end{array}$ & $\begin{array}{l}\text { A list containing all service offers provided to customers in } \\
\text { a given month. }\end{array}$ & $\begin{array}{l}\text { Approximately } 25 \text { Service } \\
\text { Offers month }\end{array}$ \\
\hline KT product plate verification & $\begin{array}{l}\text { The KT product plate contains information collected inside } \\
\text { the company: } \\
\text { - product type and characteristics, }\end{array}$ & $\begin{array}{l}\text { Approximately } 140 \text { products } \\
\text { per month }\end{array}$ \\
\hline
\end{tabular}

Statkiewicz W., Sobkowiak J., Implementing Iot (Internet of Things) Solutions on the Basis of Process Analysis and Design Thinking (on the Example of a Production Company) [in:] Adamczak M. et al., Digitalization of Supply Chains, Spatium, Radom 2019, p. 39-52. https://doi.org/10.17270/B.M.978-83-66017-86-3.4 


\begin{tabular}{|l|l|l|}
\hline $\begin{array}{l}\text { Areas identified for } \\
\text { improvement }\end{array}$ & Characteristic & Current state \\
\hline & - product components, & \\
\hline Creating Service File & $\begin{array}{l}\text { Follow-up of previous service activities necessary to sell } \\
\text { service services. }\end{array}$ & $\begin{array}{l}\text { Approximately 25 Service } \\
\text { Files per month }\end{array}$ \\
\hline
\end{tabular}

Source: own elaboration.

Due to the fact that all necessary data is collected to start the topic at earlier stages of implementation, placing the data in one interactive place would facilitate the issues of data collection and analysis. A cloud storage was proposed, which not only enables access to all interested parties, but also supports superior management. The mapping also resulted in the assumption that the preparation of service offers, their updating, as well as the creation of Service File could take place in the cloud.

The cloud storage allows the user to plan a series of reminders to make necessary updates and changes, which in the case of many topics run in parallel can be a great convenience. A necessary condition, however, is the updating of the indispensable data at earlier stages of implementation, developed jointly by all departments.

At this stage, an interactive $K T$ product plate with a $\mathrm{QR}$ code was also generated as a solution guaranteeing more efficient product identification. The QR code allows linking up the information identifying it with a specific object. Therefore, there would be no need to visit service groups in order to verify incomplete data and to check whether they are duplicated by service specialists in the IT system within the organization (P System). In addition, it was noted that assigning sales supervisors to individual customers may result in greater loyalty of clients to the company. The proposed changes are shown on the TO BE map (Fig. 2).

Statkiewicz W., Sobkowiak J., Implementing Iot (Internet of Things) Solutions on the Basis of Process Analysis and Design Thinking (on the Example of a Production Company) [in:] Adamczak M. et al., Digitalization of Supply Chains, Spatium, Radom 2019, p. 39-52. https://doi.org/10.17270/B.M.978-83-66017-86-3.4 


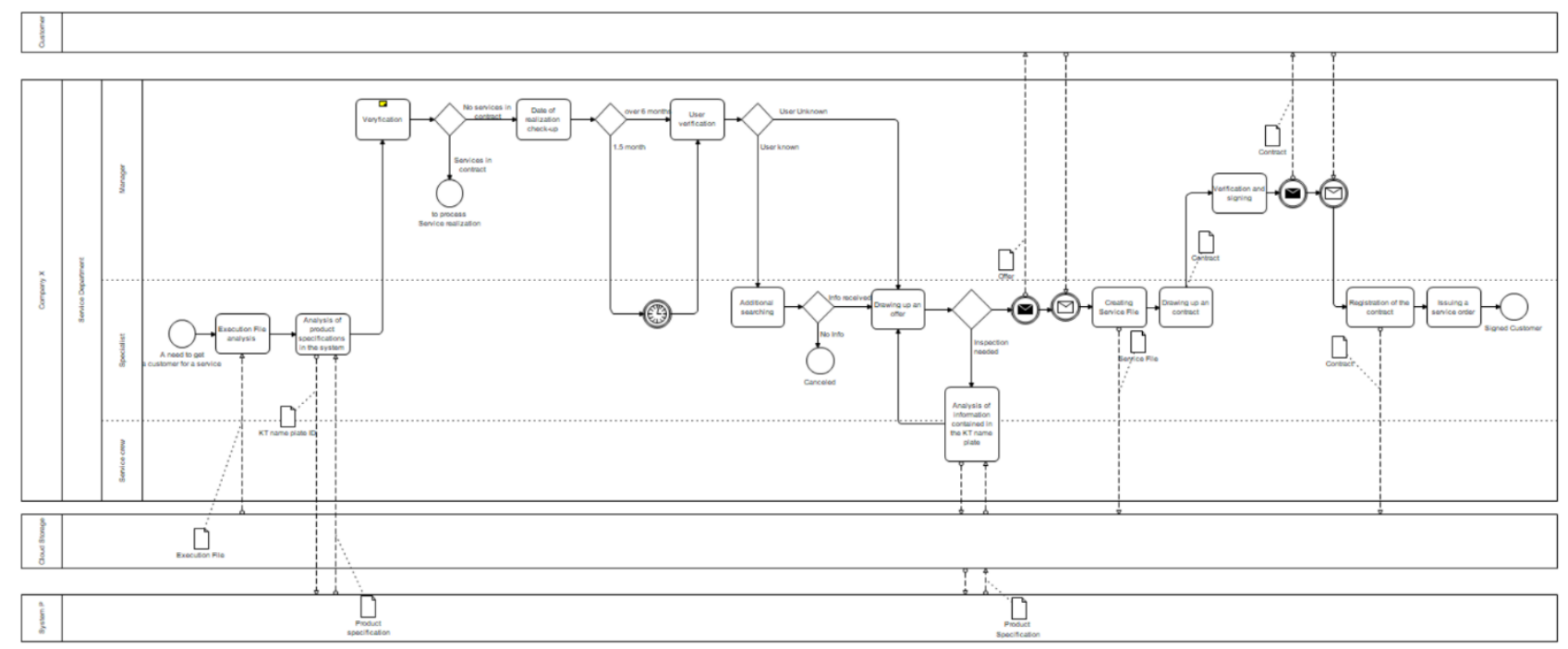

Fig. 2. The process of acquiring a customer for periodic service - TO BE.

Source: own elaboration.

The key changes in this process are:

- reduced managerial workload - any data needed for analysis is taken from a shared cloud storage and pre-processed by a specialist,

- no need to verify the date of re-offering in the Service Department, thanks to automatic system notifications - relieving the specialist from these duties while increasing the effectiveness

and accuracy of this task,

- introduction of an interactive KT product plate of the product - all necessary production data is linked up into a plate attached to the product. Customers interaction with the plate sends the X company, a set of data necessary to prepare the service,

- creation of Service File in a Storage Cloud - this procedure will allow to improve the quality of other related processes,

- a dedicated sales supervisor for individual companies - according to the analysis there is no need for additional recruitment - the resources released during automation of other processes should be sufficient to handle new tasks.

Statkiewicz W., Sobkowiak J., Implementing Iot (Internet of Things) Solutions on the Basis of Process Analysis and Design Thinking (on the Example of a Production Company) [in:] Adamczak M. et al., Digitalization of Supply Chains, Spatium, Radom 2019, p. 39-52. https://doi.org/10.17270/B.M.978-83-66017-86-3.4 
Similar problems, as in the process of acquiring a customer for a periodic service, were noticed at the next stage of the department's employees' activities. There are areas that can be eliminated in the course of the periodic inspection process.

An additional implementation proposal are RFID chips or beacons, which, when properly placed on the shelves in the warehouse, could help the Logistics Department and the Service Department

to diagnose warehouse shortages. Delegated employees, equipped with appropriate mobile applications in their phones, would receive notifications of low inventory levels.

The key changes in the process are:

- introduction of an interactive KT product plate - instead of marking with service stickers the products that have been checked, the information will be uploaded to Cloud Storage with the help of QR code. The information stored will allow service technicians to check the exact product specification before a periodic inspection and to prepare spare parts with the statistically highest probability of failure. The result would be a significant increase in the chance of express repair, which will reduce the costs associated with business travel and service technicians' working hours, but can also directly contribute to increase the customer's satisfaction,

- elimination of the activities of drawing up a protocol for the execution of service activities it is generated during the product status update,

- additional supervision over warehouse inventory through chips or beacons - this is to improve warehouse logistics management, which will have a direct impact on the improvement of the discussed processes.

\section{RESEARCH RESULTS}

The study combined two methods: process analysis and Design Thinking to optimize intraorganizational processes and develop new solutions to improve processes performance. At the analyzed stage of the study, the authors considered the combination of both methods to be more effective than when individual methods were used separately. The combination of: identifying customer needs, standardized process analysis, creativity and prototyping allowed to identify a number of solutions for the examined company that can be implemented.

Statkiewicz W., Sobkowiak J., Implementing Iot (Internet of Things) Solutions on the Basis of Process Analysis and Design Thinking (on the Example of a Production Company) [in:] Adamczak M. et al., Digitalization of Supply Chains, Spatium, Radom 2019, p. 39-52. https://doi.org/10.17270/B.M.978-83-66017-86-3.4 
In order to increase X's competitive advantage, it was proposed to use the latest technologies within the scope of optimisation activities. It was noted that the implementation of several solutions related to the Internet of Things may significantly improve the functioning of the whole process.

The concept of the Internet of Things was created in 1999 by Kevin Ashton who described it as ,a network of interconnected objects" [Ashton, access: 2009]. The idea behind the IoT is to connect intelligently, through a network of Internet devices, machines, products or dedicated programs that collect data and share it with each other, creating added value through this relationship.

Manufacturing of personalized services or products in the industry requires dedicated business solutions. They are developed in close cooperation with the customer, after a thorough analysis of his needs - they are to be manufactured as customized products, while maintaining the costs and prices of mass production. The advanced concept of the IoT assumes combining industrial devices and systems into advanced cyber-physical systems, resulting from interorganisational cooperation. These innovative ways of communication within the organization, with customers and subcontractors are, however, inaccessible to small and medium enterprises (SMEs). The costs of their implementation are too high and most entities cannot implement the desired advanced solutions within their own structures. The authors of the article encountered similar problems in X company, therefore, in order to obtain business value from the use of the IoT it was necessary to take an appropriate approach to data analysis and implementation of automation.

At the stage of proposing dedicated solutions, the following architecture of tools, which make up the IoT solutions, was assumed:

- products that can communicate, transmit information in real time (online) or collect it (offline),

- intra-organizational network mediating in relations of company's teams and contacts with clients,

- an IT system that supports the collection and processing of data, as well as their transfer to equipment and relevant products.

Statkiewicz W., Sobkowiak J., Implementing Iot (Internet of Things) Solutions on the Basis of Process Analysis and Design Thinking (on the Example of a Production Company) [in:] Adamczak M. et al., Digitalization of Supply Chains, Spatium, Radom 2019, p. 39-52. https://doi.org/10.17270/B.M.978-83-66017-86-3.4 
The guarantee of achieving the highest possible intra-organizational value from the implementation of dedicated solutions is their proper selection and proper approach to data analysis within the involved team, and on a wider scale - throughout the entire organization. Taking into account the financial capabilities of the company and the team's approach to change, after a process analysis supported by the Design Thinking method, the following solutions were proposed:

\section{Cloud Storage.}

One data set, established at the stage of creating an offer for the client and updated at subsequent levels of implementation. It should contain the documents necessary for inspection, which would save time for the team at the stage of taking over the implementation and would guarantee greater completeness of documentation. New Microsoft solutions, which are widely used within the organization, were proposed as an application base. The basis for the solution would be Microsoft Teams service based on cloud-based data, containing services and a range of tools for teamwork [Microsoft Teams: 7 things you need to know, access: 2016] .

\section{Interactive KT product plate of the product.}

Each product manufactured by the company $\mathrm{X}$ is marked with a rating plate (KT plate) specifying its basic data. The marking with a plate is done after assembly and product inspection by the manufacturer or an authorised assembly company. It is possible to place a QR code, which would be connected to the product database, on the plate. The QR code can be used by the customer to contact the Service Department in case of failure or the need to inspect the product. For the team, this solution would guarantee direct, detailed product identification.

\section{RFID chips or beacons - support for warehouse management.}

Additional help in more efficient customer service of the service department (but not only) can be the use of RFID chips (radio-frequency identification) hidden in the shelves, which with almost $100 \%$ accuracy will determine how many pieces of product remain on the shelf and signal the need to order goods. A similar proposed method are beacons - simple devices that use Bluetooth protocol to send information to nearby smartphones with appropriate application software to read this information. 


\section{Dedicated Customer Sales Supervisor}

It would be extremely helpful for the Service Department to support its customers by dedicating individual customers to them. Employees could be additionally trained in the IoT-related solutions, which would greatly facilitate the implementation of the proposed changes and improve communication between the customer and the company.

The authors of the article noted that the use of the Internet of Things in the company's development strategy creates many opportunities to gain a competitive advantage. The benefits of the IoT solutions include: cost reduction, increased productivity, more efficient use of internal resources and improved customer relations. The conducted research allowed to generate ideas allowing to increase the effectiveness of the company in the areas investigated and to initially design their implementation as well as to identify the basic phases of the implementation of projects based on the IoT in the company. These stages should be expanded and described in subsequent articles on this subject.

\section{REFERENCES}

Ashton K., 2009, That 'Internet of Things' Thing, https://www.rfidjournal.com/articles/view?4986/ [access: 22.06.2009].

Banaszczyk P., 2007, U podstaw metodologii nauk o zarządzaniu. Współczesne Zarządzanie nr 1, 90-92.

Banaszczyk P., Urbanowska-Sojkin E., 2007, Swoistość ewolucji zarządzania strategicznego przedsiębiorstwem. Współczesne Zarządzanie nr 4, 29-39.

R.Shapiro, S.White, C.Bock, 2010, BPMN 2.0 Handbook [in:] BPMN 2.0 Handbook Second Edition: Methods, Concepts, Case Studies and Standards in Business Process Modeling Notation (BPMN), 130-150.

Czakon W., 2012, Sieci w zarządzaniu strategicznym, Wolters Kluwer Polska, Warszawa.

Czakon W., 2005, Istota relacji sieciowych przedsiębiorstw. Przegląd Organizacji nr 9, 10-13.

Fertsch M., Cyplik P., Hadaś Ł., 2010, Logistyka produkcji. Teoria i praktyka, ILiM.

Grant R.M., 2005, Contemporary Strategy Analysis, Oxford.

Griffin R.W., 2007, Podstawy zarządzania organizacjami, Wydawnictwo Naukowe PWN, Warszawa.

Statkiewicz W., Sobkowiak J., Implementing Iot (Internet of Things) Solutions on the Basis of Process Analysis and Design Thinking (on the Example of a Production Company) [in:] Adamczak M. et al., Digitalization of Supply Chains, Spatium, Radom 2019, p. 39-52. https://doi.org/10.17270/B.M.978-83-66017-86-3.4 
Hakkanson H., Johanson J., 2001, Business network learning - Basic considerations [in:] Business Network Learning, Elsevier Science, Oxford, 1-16.

Hakkanson H., Snehota I., 1995, Developing Relationships in Business Networks, Routledge London.

Jaworowska M., Piątek Z., 2016, Przemysł 4.0 - czwarta rewolucja przemysłowa na świecie. Automatyka, Podzespoły, Aplikacje, nr 6(10), 24-27.

Integrated Project Delivery Frequently Asked Questions, 2016, AIA California Council.

Kaleta A., Witek-Crabb A., 2009, Nowoczesny model zarządzania strategicznego koncepcja badawcza, Wydawnictwo Uniwersytetu Ekonomicznego, Wrocław.

Lorenz M., 2015, Industry 4.0 - how intelligent machines will transform everything we know, https://www.ted.com/talks/[access: 01.12.2017].

Mahoney J., Qian L., 2013, Market frictions as building blocks of an organizational economics approach to strategic management. Strategic Management Journal nr 34, 777 780.

Microsoft Teams: 7 things you need to know, 2016, https://www.cnet.com/news/microsoftteams-7-things-you-need-to-know/ [access: 2.11.2016].

Noga A., 2011, Teorie przedsiębiorstw, Polskie Wydawnictwo Ekonomiczne, Warszawa.

Planowanie strategiczne, 1993, ed. by Klasik A., PWE, Warszawa.

Rifkin J., 2012, Trzecia rewolucja przemysłowa, Sonia Draga, Katowice.

Ratajczak-Mrozek M., 2010, Sieci biznesowe a przewaga konkurencyjna przedsiębiorstw zaawansowanych technologicznie na rynkach zagranicznych, Wydawnictwo Uniwersytetu Ekonomicznego w Poznaniu, Poznań, 77-90.

Romanowska M., 2004, Planowanie strategiczne w przedsiębiorstwie, PWE, Warszawa. Sommer L., 2015, Industrial revolution - industry 4.0: Are German manufacturing SMEs the first victims of this evolution?. Journal of Industrial Engineering and Management $\mathrm{nr}$ 8(5), 1512-1532.

Wąsowska A., 2012, Współczesne koncepcje zarządzania strategicznego [in:] Nowe kierunki w organizacji i zarządzaniu, ed. By B. Glinka, M. Kostera, Oficyna Wolters Kluwer Business, Warszawa, 380-395.

Zarządzanie strategiczne. Problemy, kierunki badań, 2009, ed. by Krupski R., PNW, Wałbrzych. 